\title{
THE CONTEXTS OF THE STUDENT TAKING THE MICRO TEACHING CLASS
}

\author{
Hongki Julie \\ Sanata Dharma University \\ hongkijulie@yahoo.co.id \\ https://doi.org/10.24071/ijiet.2017.010206 \\ received 10 April 2017; revised 29 May 2017; accepted 30 June 2017
}

\begin{abstract}
In this paper, the researcher would only present the results obtained by the researcher related to the context of students. To find out the context of the students who took this course, the researcher did the taking: (1) find the students' hometown data and the students' GPA from the Sanata Dharma Academic Information System (SDAIS), and (2) make a questionnaire consisting of four questions filled by students at the first meeting. The results of this research was as follows: (1) ten students came from Java Island and nine students came from outside Java Island, (2) six students had GPA above 3.00 and thirteen students hadGPA below 3.00, (3) eleven students said that their vocation was to be a teacher when they first chose this program, (4) there were 13 students who experience change of vocation, and (5) there were eighteen students who stated that their obstacles in taking this lecture were "I had not "settled" with myself," while one other student said that "mastering teaching materials was my obstacle in taking this lecture."
\end{abstract}

Keywords: Reflective Pedagogy Paradigm (RPP), context, experience, action, reflection, and evaluation.

\section{Introduction}

The course was aimed to equip students with basic teaching skills, such as opening and closing lessons, explaining and varying stimulus skills, and asking and strengthening skills, and equipping students with the skills to apply a particular learning approach / model. This course was the pre-requisite subject for the Program Pengalaman Lapangan course. From the researcher's experience in this course, there were some aspects that needed to be improved, namely:

1. Students' enthusiasm in managing learning. Some students were not enthusiastic in managing learning because the students taught the other students who took this lecture were not the real learners. This causes the learning process that occurs was not dynamic.

2. When preparing the lesson plan (RPP), students were not critical in looking at the relationship between basic competencies, indicators, and evaluation questions provided to learners. Students were also not critical in looking at the relationship between learning methods and learning activities. 
3. Because the role of students was their own partner, the concern and love of learners could not be built optimally.

These things would be improved by the researcher in this year's micro teaching school.

The formulation of the research question to be answered in this paper was how the profile of students who took the Micro Teaching course?

Komunitas Studi dan Pengembang PPR Yogyakarta defined the pedagogy as the effort made by teachers in assisting students in their growth and development (Komunitas Studi, 2012). According to Komunitas Studi dan Pengembang PPR Yogyakarta, pedagogy was closely related with the teachers' beliefs and vision about a personal ideal figure to be formed through a teaching and learning process (Komunitas Studi, 2012). According to Father Arrupe, the goal of the Jesuit education was to construct men and women for others (Komunitas Studi, 2012). Father Kolvenbach formulated that the aim of the Jesuit education was to form leaders of ministry, men and women who were competent in their fields, have a conscience that was true, and has a compassion that grewout of love to others (Komunitas Studi, 2012). According to Preis and Stauder, the Jesuit education would achieve all Jesuit university core values to seek other forms of assistance for students called cura personalis approach which means caring for each individual must be consistent with the character and potential of each individual (Preis \& Stauder, 2014).

There were five educational principles in the RPP (Metts, 1995; Suparno, 2015; \& Preis \& Stauder, 2014), namely:

1. Context

According Preis and Stauder, the students' contexts were the things that the teacher need to know about their learners (Preis \& Stauder, 2014). In preparing the teaching and learning process with the RPP, a teacher needed to recognize with the context of their students, include: the context of individual students, the initial concept and knowledge of the students, the context of the economic, social, political, cultural, and media, the college environment, and educational context in Indonesia (Komunitas Studi, 2012 \& Suparno, 2015). Why recognize the initial concept and knowledge of the students was important for ateacher? Skemp said a scheme had three functions, namely: (1) integrate existing knowledge; (2) a tool for learning; and (3) make someone understand something (Skemp, 2009). Therefore, if a teacher knew about the initial concept and knowledge of their students, then the teacher was expected to create appropriate learning path for their students, and plan the appropriate scaffolding for their students (Skemp, 2009).

2. Experience

On the experience elements, the teacher need to create situations that could make the students to gather and remember their experience. These experience used by them to sift the facts, feelings, values, understanding, and intuition thatknew by them and to make a connection with what they were learning (Komunitas Studi, 2012). According to Preis and Stauder, the experience was the best effort that could be done by the teacher in using all the students' potential to achieve the learning objectives (Preis \& Stauder, 2014). 


\section{Reflection}

In the reflection element, students were helped to dig their experiences owned by the students in-depth and extensive, and to take the meaning for their personal life, and others [Suparno, 2015]. In the reflection, memory, understanding, imagination and feeling were used to grasp the basic meaning and values from the material being studied by them [Komunitas Studi, 2012]. According to Preis and Stauder, a reflection was the efforts done by the teacherthat made their learners to explore their experiences in greater depth (Preis \& Stauder, 2014).

4. Action

In the action element, students were helped to do good actions which were at the mind level or the physical activity level after they reflected on their learning experience [Suparno, 2015]. According to Paul Suparno, an action might be a changing attitude that was better than before, and a real action which was directed out of themselves that could be seen and felt by others [Suparno, 2015]. According Preis and Stauder, the action was the effort made by the teacher encouraged their students to move from knowledge into a concrete action (Preis \& Stauder, 2014).

\section{Evaluation}

The evaluation element could help the teacher to understand that the element of experience, reflection, and action has been available well in the teaching learning process or not. The purpose of the evaluation was to look thoroughly whether the learning process with the RPP has occurred or not and whether the learning process could help students to develop their competence, conscience, and compassion for others or not. The evaluation was also to see whether the scaffolding provided by the teacher during the learning could developthe students or not [Suparno, 2015]. According Preis and Stauder, evaluation was an attempt used by the teacher to assess the learners progress in competence, conscience, and compassion for others (Preis \& Stauder, 2014).

\section{Method}

In a qualitative study, the researcher sought to describe a phenomenon that occurs in a natural situation and not make a quantification of the phenomenon (Merriam, 2009 \& Miles \& Huberman, 1994). This research was classified in qualitative research, because in this study the researcher sought to describe a phenomenon that occurs in a natural situation and not make a quantification of the phenomenon. The natural phenomenon that seeks described in this study was the context of students taking the Micro Teaching and Learning Class.

The subject of this research was all the students taking Micro Teaching and Learning Class on Class C. There were 19 students who were the subject of this research consisted of six male students and 13 female students.

The study consisted of five cycles. Each cycle consists of four main elements, namely experience, action, reflection, and evaluation. The learning process in the first cycle was to construct the skills to open and close the lesson. The learning process in the second cycle was to construct skills to explain and vary the stimulus. The learning process in the third cycle was to construct the 
skills to ask questions and provide reinforcement. The learning process in the fourth and fifth cycles were to construct integrating skill on the skills of opening and closing the lessons, the skills of explaining and varying the stimulus, and the skill of asking and providing reinforcement. This cyclical process was preceded by the researcher with students' context recognition activities. In this paper, the researcher would only present the results obtained by the researcher related to the context of students in the first cycle.

\section{Findings and Discussion}

The student's home area by province, namely:

1. There were three students who came from the Bangka Belitung province.

2. There was one student who came from the Lampung province.

3. There were two students who came from the Banten province.

4. There was one student who came from the West Java province.

5. There was one student who came from the Yogyakarta province

6. There were six students who came from the Central Java province.

7. There were four students who came from the West Kalimantan province.

8. There was one student who came from the East Nusa Tenggara province.

The GPA achieved by students up to the fifth semester may be classified as follows:

1. There were six students who had the GPA between 3.00 and 3.49.

2. There were eight students who had the GPA between 2.50 and 2.99.

3. There were three students who had the GPA between 2.00 and 2.49.

4. There were two students who had the GPA between 0.00 and 1.99.

To know the context of students who took this lecture in more depth, the researcher made a questionnaire with four questions. The questionnaire was given to students on the first meeting. Four questions given by the researcher to the students were as follows:

1. Is my life goal to become a teacher? Why did you choose a life goal to be a teacher?
a. At first I chose this program.
b. Currently.
c. What things / events changed me?
d. Why did it change me?

2. What does being a teacher as a life goal mean to me?

3. What abilities did I want to develop through this lecture? Why did I want to develop it?

4. What was my obstacle to join this course? Why could it be an obstacle? Have I already had a solution? What solution do I have?

The first question of the questionnaire was to explore the context of the students related to (a) their motivation into the mathematics course, (b) there was a change of motivation or not after they enrolled in this program for 5 semesters, and (c) if there was a change of motivation what causes the student to experience a change in motivation, and (d) if there was a change of motivation, why it can change their motivation. The second question of the questionnaire was to explore the context of the students related to the meaning of the teaching profession for 
them. This information was important for the researcher to see what the student's vision of life was related to the teaching profession. The third question was intended to explore the context of students related to the things they want to develop in this course in order to become a professional teacher and what skills were generally still felt less than the students who attend this course. The fourth question was to explore the context of the barriers that students had and what solutions they had to overcome these obstacles. An answer to this question would assist the lecturer in identifying the barriers most students had in taking the lecture.

Answers to the four questions above would be described as follows:

1. Is my life goal to become a teacher? Why did you choose a life goal to be a teacher?

a. Eleven students said that their vocation was to become a teacher when they first chose this program. Seven students said that their vocation was not tobe a teacher when they first chose this program. One student said that hewas hesitant to choose a vocation as a teacher when they first chose this program. The reasons for those who answered that their vocation was to become a teacher when they first chose this program were as follows:

1) The reason given by five students was one of the parents was a teacher.

2) The reason given by the three students was that "I love the exact sciences", "I want to share knowledge with others, and became role models for my students."

3) The reason given by one student was "I would be easier in finding a job."

4) The reason given by one student was the teacher helped the creation of all professions and characters.

5) The reason given by one student was that "I want to omit the assertion that mathematics was difficult, and I want to help my students to look and feel that mathematics was beautiful."

The reasons those who answered that their vocation was not to be a teacher when they first chose this program were as follows:

1) The reason given by three students was the parents who asked them to choose this program.

2) The reason given by the two students was that they did not have a vocation as a teacher.

3) The reason given by the two students was "I could not afford to study in this program."

4) The reason given by one student was because it was not accepted in other study program.

The reason for the students who answered that they were hesitant to choose a vocation as a teacher when they first chose this program was because they want to share to others.

b. Fifteen students said that their current vocation was to become a teacher. Four students said that currently they were hesitant to choose a vocation as a teacher. 
The reasons for those who responded that their current vocational life to be teachers were as follows:

1) Four students said their reason was "at the moment I believe I could be a good teacher."

2) Three students said their reason was "I want to share my knowledge with those in need."

3) Two students said their reason was they want to educate the nation's future generation by improving the quality of education.

4) One student said my reason was because "at this time I understand more about mathematics."

5) One student said "my reason was because my parents were teachers and they want their children to follow their footsteps."

6) One student said "my reason was I have a desire to build a positive character in students, so they can grow and develop positively."

7) Three students did not give a reason.

The reasons by those who answered that they were currently hesitant to choose a vocation as a teacher were as follows:

1) Two students said their reason was "I am plagued with some courses that I could not understand."

2) Two students said their reason was because "I am still confused by the job of being a teacher."

c. There were 13 students who experienced a change of vocation. Two students experienced a change in motivation, originally extrinsic motivation now turned into intrinsic motivation. The thing that caused change was the opportunity to do activities in school.

d. Eight students experienced a change of vocation, in the earlier they did not want to become a teacher, but now they want to be a teacher. Things that caused change:

1) Three students said the reason for the change was because of the opportunity to do activities in school.

2) Two students said the reason for the change was because they saw the surrounding environment that there were still many who need the existence of teachers.

3) One student said the reason for the change was that "I was afraid to disappoint the parents."

4) One student said the reason for the change was that my parents were teachers.

e. One student experienced a change of vocation, in the earlier she hesitantly wanted to become a teacher, but now she wants to become a teacher. The thing that "caused me to change was the opportunity to do activities in school."

f. Two students experienced a change of the vocation. At first, they wanted to be a teacher, but then they were hesitant to become a teacher. The thingsthat caused them to change were (1) I was not confident to teach in front of the class. Because I was not yet sure of my ability; (2) I know from the 
course that the administration that the teacher needs to be prepared was quite a lot and heavy.

2. What does to have a life goal as a teacher for you?

a. There were six students who answered that the teacher was a teacher and an educator for learners.

b. There were four students who answered the teacher to be a determinant of the development of the nation because the teacher becomes the root for the young people, "food" for the development of young people.

c. There were three students who answered that the teacher was a leader and role model for learners.

d. There were three students who answered that the teacher was a science developer.

e. There were three students who answered the teacher was a waiter for the students.

3. What abilities did I want to develop through this lecture? Why did I want to develop it? Things I want to develop through this lecture:

a. The ability to deliver materials.

b. The ability to become a qualified and humanist teacher.

c. The ability to manage my class.

d. Teaching skills.

e. The ability to teach in front of class.

f. The ability to communicate.

g. A courage and self confidence.

h. The ability to know the difficulties faced by students. My reasons were:

a. Because the teacher was the creator of all professions and characters.

b. In order to create a conducive and active class.

c. Because my skills in teaching were still minimal and still groggy when teaching.

d. Because my ability in communication still needs to be improved.

e. My courage and self-esteem were still lacking, especially when I teach in front of the class.

f. To be a good teacher.

g. In order to provide the right solutions for student difficulties.

4. What was your obstacle to take this course? Why could it be an obstacle? Did you already have a solution? What solution do you have?

My obstacles were:

a. I have not "settled" with myself, suppose I was not confident, I was afraid, I was lazy, I was not disciplined. There were eighteen students who have obstacles in this regard.

b. I did not master the material that I taught. There was one student who had obstacles in this regard.

My solutions were:

a. I practiced communicating with other people. There were eight students who chose this solution. 
b. I thought positively to myself that I could. There were four students who chose this solution.

c. I often repeat in studying the lecture materials that I've studied. There was one student who chose this solution.

d. I made a time table. There was one student who chose this solution.

From the previous explanation, the researcher saw that one of the factors that was quite proposing in changing the student motivation so that they had the life goal as a teacher was the activity in the school, especially their interaction with the students. Therefore, in the teaching and learning process in this course, the researcher planned to ask students to teach at least one school for one lesson. When the students taught in the real class, then the researcher would accompany them in the classroom. If students had difficulty, then the researcher could provideguidance directly to them. The existence of this process made that students experience learning by doing teaching learning process.

The mentoring process was also intended by the researcher to improve students' courage and confidence. The researcher assumed with the researcher in the classroom, it will made them feel "safe" and "comfortable" when doing the learning process. Because if they had difficulties when they manage the learning process, they could discuss with the researcher to find ways to overcome the difficulty.

One of the expectations of students who attended this lecture was that they can develop skills in managing learning. From the previous teaching and learning experience, the researcher got the fact that the knowledge and skill of the students in managing learning with particular learning models were very less. For these two reasons, the researcher planed in the learning process of micro teaching lessonthis year, the researcher would invite the students to deepen their knowledge and skill in managing the learning with certain learning models. The learning models chosen by the researcher to be studied this year were cooperative learning model, problem based learning model, learning model with scientific method, and learning model with realistic mathematics education approach.

The students' knowledge of the models is enhanced in the taking ways: (1) students were divided into groups consist of 2 - 3 students, (2) each group got a task to study a learning model and make a paper related to the learning model that they were studying, (3) each group presented their outcomes to the other students, and (4) the researcher gave a reflection question to make the students explore each learning model. The students' skills in managing learning using these models were improved in the taking ways: (1) ask students to make lesson plans for a particular subject using the learning model they previously held, (2) the students were given the opportunity to consult (3) students were asked to practice their lesson plans in the school and accompanied by the researcher, and (4) students made reflections on the implementation of the learning management they have done.

\section{Conclusions}

From the previous explanation, there were some things that could be concluded by the researcher about the contexts of students who took the micro teaching course in class C. First, 10 students came from Java Island and nine 
students came from outside Java Island. Second, six students had a GPA above 3.00; while 13 students had a GPA below 3.00. Third, 11 students said that their vocation was to be a teacher when they first chose this program. Fourth, there were 13 students who experienced change of vocation. The factors that made the most change were due to the opportunity to do activities at school and interact with students at school. Finally, there were 18 students who stated that their obstacles in taking this lecture were I had not "settled" with myself, while one other student said that mastering teaching materials was my obstacle in taking thislecture.

\section{References}

Komunitas Studi dan Pengembang PPR Yogyakarta. (2012). Paradigma Pedagogi Reflektif. Yogyakarta: Penerbit Kanisius.

Merriam, S. B. (2009). Qualitative research: A guide to design and implementation. San Francisco: Jossey Bass A Wiley Imprint.

Metts, R. E. (1995). Ignatius knew. Washington DC: Jesuit Secondary Education Association.

Miles, M. B. \& Huberman, A. M.. (1994). Qualitative data analysis. London: Sage Publications

Preis J. \& Stauder E. (2014). Reflective writing: From pedagogy to practice in a Jesuit university. Journal Jesuit Higher Education, 3(1), 29- 39.

Skemp, R. (2009). Psychology of learning mathematics. New York: Routledge.

Suparno, P. (2015). Pembelajaran di peguruan tinggi bergaya Paradigma Pedagogi Reflektif. Yogyakarta: Penerbit Universitas Sanata Dharma. 